\title{
Leveraging Emerging Technology to Design an Inclusive Future with Universal Design for Learning
}

Don Douglas McMahoN ${ }^{* 1}$ AND ZaChary WALKeR ${ }^{2}$

$\approx$ The aim of this article is to explore the opportunities and challenges that arise with the proliferation of new technology, to provide an understanding of why it is important to try new strategies in education, and to provide an inclusive framework for experimentation using tools such as robotisation, automatisation, artificial intelligence and immersive learning. Significant challenges exist in implementing transformative technologies with a limited or non-existent evidence base for their use, and designing inclusive educational experiences with a limited evidence base is even more challenging. In order to address this need, the article presents some ways in which educators can make informed implementation decisions around these new tools. First, we examine the rule of the least dangerous assumption, which supports trying new technologies even if the evidence base is lacking. Next, we present a strategy that educators can use to apply the research-based framework of UDL in order to make informed implementation choices with new technologies. Finally, based on information gained from experience in providing professional development, school level implementation, individual student interventions and teacher focus groups, we offer some recommendations for practice. We present several fun propositions that can help create a culture to support educators as they endeavour to create inclusive educational experiences with emerging technologies. We also explore current trends in technology use, describing and providing practical examples of implementation and integration to support a more inclusive future with emerging technologies.

Keywords: educational technology, universal design for learning, accessibility, immersive technology

$1{ }^{\star}$ Corresponding Author. Washington State University in Pullman, Washington, United States of America; don.mcmahon@wsu.edu.

2 University College, London Institute of Education, United Kingdom. 


\section{Izkoriščanje porajajoče se tehnologije za oblikovanje vključujoče prihodnosti z univerzalnim modelom za učenje}

Don Douglas McMahon in Zachary Walker

$\propto$ Namen prispevka je raziskati priložnosti in izzive, ki vznikajo $\mathrm{z}$ množitvijo novih tehnologij, ponuditi vpogled $\mathrm{v}$ razloge, zakaj je pomembno preizkušati nove strategije $\mathrm{v}$ izobraževanju, in ponuditi vključujoč okvir za eksperimentiranje z uporabo orodij, kot so: robotizacija, avtomatizacija, umetna inteligenca in potopitveno učenje. Pri implementaciji transformativnih tehnologij, za uporabo katerih stoji le malo ali nič podpore v dejstvih, obstajajo številni izzivi, še toliko večji izziv pa predstavlja oblikovanje vključujočih izobraževalnih izkušenj, za katere prav tako obstaja le omejena podpora $v$ dejstvih. Da bi naslovili to potrebo, v prispevku predstavljamo nekaj načinov, na katere lahko izobraževalci opravljajo informirane odločitve glede implementacije teh novih orodij. Najprej bomo preučili pravila najmanj nevarne predpostavke, ki podpira preizkušanje novih tehnologij, tudi če manjka podpora dejstev. V nadaljevanju bomo predstavili strategijo, ki jo izobraževalci lahko uporabljajo za implementacijo na raziskovanju utemeljenega okvira UDL, ki omogoča sprejemanje informiranih odločitev o implementaciji novih tehnologij. V sklepnem delu bomo na podlagi informacij, ki smo jih pridobili iz izkušenj v izvajanju strokovnega razvoja, implementacij na ravni šol, posegov na ravni posameznih učencev in fokusnih skupin z učitelji ponudili nekaj predlogov za prakso. Predstavili bomo nekaj zabavnih predlogov, ki lahko prispevajo k ustvarjanju kulture, ki izobraževalce podpira $\mathrm{v}$ njihovih poskusih ustvarjanja vključujočih izobraževalnih izkušenj s porajajočimi se tehnologijami. Prav tako bomo raziskali trenutne smernice v rabi tehnologije ter opisali in ponudili praktične primere implementacije pa tudi integracije, ki s porajajočo se tehnologijo podpirajo bolj vključujočo prihodnost.

Ključne besede: izobraževalna tehnologija, univerzalni model za učenje, dostopnost, potopitvena tehnologija 


\section{Introduction}

If an education revolution is going to occur through the adoption of new technologies, now is the time to begin the design process in order to make this new educational paradigm as inclusive as possible. Robotisation, automatisation, artificial intelligence and immersive learning tools will lead to new opportunities in education with wide-ranging implications, as we prepare learners for this shift in employment opportunities, social activities and broader engagement with the world. The aim of this article is to explore the opportunities and challenges that arise from using new technologies in education, and to provide a path to implementation. This implementation path is based on the following elements: One Rule, a research-based framework, and five propositions to guide educators seeking to effectively use emerging technologies in education.

In addition to certain challenges that new technologies may create, it is also important to recognise the potential for positive applications of these new tools to empower a more inclusive world. In 1988, Mary Pat Radabaugh, a director at IBM, stated, "For most people technology makes things easier. For people with disabilities, however, technology makes things possible. In some cases, especially in the workplace, technology becomes the great equalizer and provides the person with a disability a level playing field on which to compete". It is important that we design technology with this in mind: for individuals with disabilities, technology is not a luxury but a necessity. The current exponential rate of technology development presents educators, students and other stakeholders with some unprecedented challenges. A simple example of this challenge is how quickly new technologies become widespread. Consider that the telephone took 75 years to reach an audience of 50 million users, while the mobile app Angry Birds only needed 35 days to reach 50 million users (Aeppel, 2015). While Angry Birds is just a mobile game app not focused on education (but still really fun), it is a prime example of the challenges educators face connecting rapidly emerging technology to curriculum and instructional strategies.

This exponential rate of technology adoption is partially made possible by the changing way software and devices have allowed users to individualise their devices with the tools available on mobile app stores. Individuals with disabilities report that the introduction in 2008 of the Apple app store, which has apps that can customise the phone for their personal use, was life altering for them and their families (Aquino, 2018). One common example of this is the augmentative and assistive communication (AAC) app Proloquozgo and its benefits for individuals with complex communication needs (Flores et al., 2012). This mobile app allowed families to customise their own mobile devices to support the communication 
needs of students with complex communication needs. This combination of mobile devices and a mobile app allowed families to have access to high quality AAC tools at a fraction of the cost of previous specialised AAC devices (Edyburn, 2013).

\section{The Rule (The Least Dangerous Assumption)}

While in many cases it is difficult to determine what will work best when using a new technology, educators have to use their best judgement, which must be based on the premise of the least dangerous assumption. The least dangerous assumption is a rule that specifies "in the absence of conclusive data, educational decisions ought to be based on assumptions which, if incorrect, will have the least dangerous effect on the likelihood that students will be able to function independently as adults" (Donnellan, 1984, p. 141). For example, the proliferation of the iPad in schools took place before evidence-based practices for their use had been established (Ayres, Mechling, \& Sansosti, 2013), probably because educators perceived its usage to be non-detrimental. Prior to the release of the iPad, tablet computers had already been in use in classrooms as an educational tool. The iPad, however, facilitated both the creation of new educational material (digital books, magazines, etc.) and the installation of educational software available in the form of mobile apps (Ireland \& Woollerton, 2010), thus proving to be a flexible and significant classroom aid for both teachers and students. The same is likely to be true of other emerging educational technologies.

If we are going to take advantage of new technologies to create an inclusive world, however, it is important that we strive for inclusion and accessibility, so that all people can benefit from these new learning resources. We view this as a Prime Directive for educators: when in doubt about using a new technology, return to the least dangerous assumption. In a time of rapid technology adoption and innovation, we need to apply the least dangerous assumption to empower our students with these new tools. Fortunately, we have the researchbased framework of Universal Design for Learning, which can help us to effectively implement these tools in powerful learning experiences.

\section{Learning with Emerging Technology Informed by Uni- versal Design for Learning}

Emerging technologies such as robotisation, automatisation and artificial intelligence, as well as immersive learning platforms like augmented reality, virtual reality and wearable devices, are potentially powerful educational tools that can benefit diverse groups of learners, including learners with disabilities. Educators interested in 
implementing these tools face a variety of implementation challenges, including the lack of an evidence base for the effectiveness of a new technology and clear strategies on how to best implement these technologies in educational settings. Based on Donnellan's (1984) least dangerous assumption, however, educators can begin to implement new technologies with the goal of helping students to be as familiar with the use of these tools as adults. We believe that the Universal Design for Learning framework is an ideal strategy for the effective implementation of these emerging technologies.

We cannot expect an emerging technology to have a strong evidence base of peer-reviewed articles supporting its effectiveness early in its implementation. However, we can implement emerging technologies using a research-informed strategy by connecting these tools to the framework of Universal Design for Learning (CAST, 2018). Universal Design for Learning (UDL) is a theoretical framework connected to neuroscience, learning sciences and cognitive psychology (CAST, 2011). It identifies affective, recognition and strategic networks that correspond to the three broad principles of UDL:

- $\quad$ Provide Multiple Means of Representation

- $\quad$ Provide Multiple Means of Action and Expression

- $\quad$ Provide Multiple Means of Engagement

Each principle includes specific guidelines and checkpoints to support implementation, as shown in Figure 1 below.

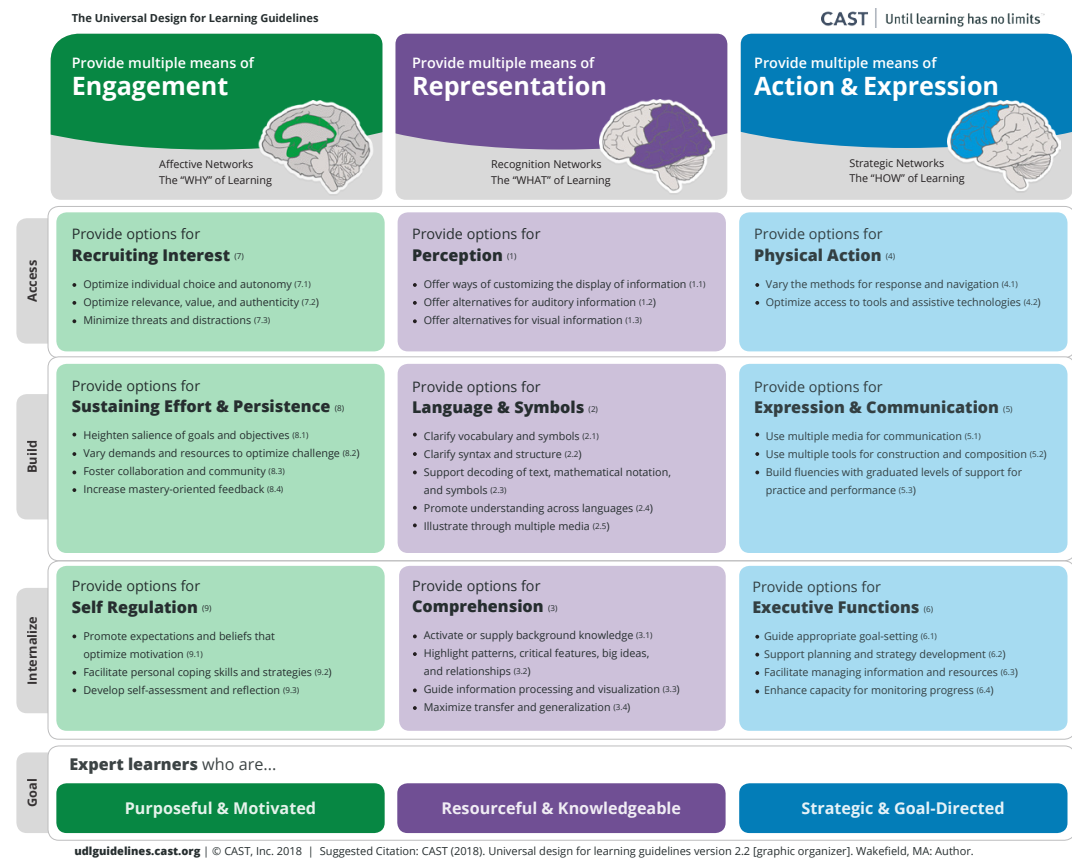

Figure 1. UDL Guidelines and Checkpoints Graphic by CAST (2018). 
In the United States Higher Education Opportunity Act 2008, UDL is defined as "a scientifically valid framework for guiding educational practices that: (A) provide flexibility in the ways information is presented, in the ways students respond or demonstrate knowledge and skills, and in the ways students are engaged; and

(B) reduce barriers in instruction, provide appropriate accommodations, supports, and challenges, and maintain high achievement expectations for all students, including students with disabilities and students who have limited English proficiency." (HEOA, 2008, p. 110)

This policy definition supports the definition of UDL established by Rose and Meyer (2002) and updated by CAST (2011). According to Rose and Meyer (2006), the nine guidelines in the UDL framework, three for each major principle, can be used to scaffold instructional practices in ways that are similar to the scaffolding of learning described by Vygotsky. Turnbull, Wehmeyer and Turnbull (2007) described how the UDL framework also applies as a cognitive taxonomy that provides lists of cognitive skills or activities similar to the Cognitive Taxonomy developed by Bloom (1956). By building on the work of researchers in cognitive theory, UDL provides a scientific framework for designing curricula that articulates a method of teaching for learning based on planning to include learners with diverse strengths. Employing this strategy, several researchers have used the UDL framework to inform their decision-making and evaluation process regarding technology interventions for students (Almond et al., 2010; Dolan, Hall, Banerjee, Chun, \& Strangman, 2005; Hall, Strangman, \& Meyer, 2003).

UDL is a complex topic that can be challenging to implement at scale while measuring outcomes (Edyburn, 2010, p. 40). As we near a decade since Edyburn's article "Would you recognize universal design for learning if you saw it? Ten propositions for new directions for the second decade of UDL" there has been some significant progress. In his article, Edyburn presented ten propositions challenging the current state of UDL implementation. In the United States, UDL is now supported and endorsed in the Every Student Succeeds Act (2015) as a valuable researchbased framework for supporting all learners. The National Educational Technology Plan (2016) builds on this support for UDL throughout the report.

Education stakeholders should develop a born accessible standard of learning resource design to help educators select and evaluate learning resources for accessibility and equity of learning experience. ... Using the principles and research-base of UD and UDL, this standard would serve as a commonly accepted framework and language around design for accessibility and offer guidance to vendors and third-party technology 
developers in interactions with states, districts, and institutions of higher education. National Education Technology Plan. (2016, p. 22)

Beyond the United States, UDL is also gaining support for implementation and research internationally. In New Zealand, the Ministry of Education has implemented a UDL initiative to reduce barriers and create more inclusive educational communities (Ministry of Education, 2018). In Europe, there are several UDL implementation projects, including locations in Belgium (SIHO, 2015), Spain (ONCE, 2014) and Norway (Zero Project, 2014).

Although there has been progress since Edyburn's (2010) ten propositions for the second decade of UDL, many of the challenges identified by Edyburn still remain. For example, Scott (2018) examined special education teachers' interest in UDL and barriers to implementation. Several barriers were identified, including (a) general education teacher support for inclusion, (b) the need for administrative support, (c) the need to improve general education teacher knowledge of UDL, (d) more preservice field-based training on UDL, and (e) additional inservice training on UDL. These findings support the need for increased professional development and implementation support for UDL. In addition to the need for more resources to support UDL school implementation, there is a need to expand UDL research, especially internationally. For example, in a review of UDL research from 2012 to 2015,75 percent of the studies identified were conducted in the United States, and most of the international UDL studies were from countries that the authors identified as being culturally similar to the U.S. (Al-Azawei, Serenelli, \& Lundqvist, 2016). While, internationally, UDL is increasingly an educational framework of choice, there is a strong need for additional research on UDL implementation across multiple cultures and countries.

In order to address these challenges to relating implementation and research, the Universal Design for Learning Implementation and Research Network (UDL-IRN.org) was created. Through work groups, an annual summit and professional development, the UDL-IRN is working to support the establishment of more inclusive education for all learners. One of these work groups has established and published UDL reporting criteria for focused research (Rao, Smith, Edyburn, Grima-Farrell, Van Horn, \& Yalom-Chamowitz, 2018). These guidelines help researchers and practitioners to establish a common UDL vocabulary and an understanding of how to design inclusive education environments. The UDL Guidelines (CAST, 2018) and the UDL reporting criteria (Rao et al., 2018) are resources ideally designed to support thoughtful and inclusive implementation of new technologies that have a limited or nonexistent evidence base. 
As we enter the third decade of UDL, all ten of Edyburn's (2010) propositions remain relevant, but to address the implementation of new technologies, we are going to focus on just one of them. The sixth proposition identified was "Technology is Essential for Implementing UDL" (2010, p. 38). We strongly agree with this belief that technology is critical for creating an education environment that is accessible from the start; UDL has a strong emphasis on designing instruction from the start to be inclusive of a diverse range of learner abilities and needs.

The UDL guidelines provide a research-based instructional framework for examining the many ways that educators can implement a new technology to systematically plan for and support diverse learners. Educators can design this implementation by clearly connecting the capabilities of a new technology to a specific UDL guideline or checkpoint. McMahon and Walker (2014) examined both built-in features and third-party apps, linking them to nine UDL guidelines. This examination demonstrated that there are multiple ways that mobile phones and tablet computers are examples of how new technology tools can be connected as resources to provide UDL features for diverse learners. Walker, McMahon and Rosenblatt (2017) examined how augmented reality was a classroom-ready means of supporting UDL. This same type of strategy could be applied to emerging classroom technologies and future new technologies. For example, an educator interested in using virtual reality in the classroom might connect it to the UDL guideline of recruiting interest by having students use Google Earth in VR to "walk the streets" of a country they are studying. This strategy of directly connecting capabilities and features of lesson design (i.e., a new technology tool) and a UDL guideline is also one of the recommended reporting criteria for UDL research and implementation (Rao, et al., 2018).

\section{Five Fun Educational Technology Propositions}

One rule, the least dangerous assumption, and a strategy of connecting capabilities to the UDL framework may not be enough for some educators to take the risks and implement emerging technologies. Based on our experiences of providing professional development, school level implementation, individual student interventions and teacher focus groups, we have some recommendations for teacher practice. If a teacher needs an answer about why they are using a new classroom technology, the least dangerous assumption is a rule they can use to justify their decision. This rule supports the idea of implementation even if there is a lack of strong peer-reviewed research providing an evidence base. The UDL guidelines can provide educators with a research-based strategy to 
implement novel technologies by clearly connecting the capabilities of these technologies to a specific guideline or checkpoint. In addition, educators also need a culture around technology implementation that allows them to effectively design inclusive educational experiences with new technologies. If we are to effectively leverage emerging technologies, education systems need to develop a culture of exploration and innovation grounded in existing education frameworks and the concept of the least dangerous assumption. In order to help create this culture, the authors offer the following five fun propositions to guide the implementation process in schools and educational communities.

\section{Proposition 1. Don't (Techno) Panic}

Our first proposition is borrowed and slightly amended from the original "Don't Panic" in the Hitchhiker's Guide to the Galaxy (Adams, 1980). The motto of the book, which helps sentient beings travel the universe much like a current European travel guide, is simply "don't panic". "Don’t Techno Panic" is a reminder that, while new technologies may cause disruption, the bestand worst-case predictions often never come to pass. The term technopanic (Thierer, 2013) is commonly used to describe negative reactions, predictions and fear-based arguments about the dangers of a new technology. The history of technology is filled with bold predictions and technopanics warning that \{insert technology here\} is going to ruin \{insert something loved here\}. Many of these technopanics have revolved around children, school and education. Technopanics are not just an issue in recent history. One of the first technopanics was connected to the ill effects of the printing press. Some people believed that mass printing would lead to chaos because the proliferation of reading material and literacy would lead to confusion, as people would not have to listen to authority as much (Bell, 2010). This example is important because it shows that the human reaction to technology is not so much about the technology as it is about the human, as has been proven time and time again throughout history.

Designing the inclusive future will require us not to engage in technopanics, but to instead explore the benefits and potential of technologies as new tools. While it is often en vogue to complain about these innovations, it is important to recognise that these technologies are just tools and it is how they are used that has benefits or challenges for society. Radio, television, the computer, the Internet, wireless data, video games and mobile phones all experienced significant technopanics. Today, televisions help people learn about the world, computers have increased productivity so we can save time on many tasks, the Internet has created new industries and learning opportunities, mobile devices 
allow us to use GPS to guide our way, video games can help engage learners, and mobile devices provide built-in accessibility tools.

While new technologies will present significant challenges as society adapts, they also provide new opportunities. It is easy to be intimidated by new technologies or reminisce about what may be extinguished; our first proposition "Don't Panic" is a caution to stay grounded and not overplay the potential perils of a new technology. In order to address making emerging technologies inclusive, researchers, educators and advocates across many fields need to be engaged in bringing them into the mainstream.

\section{Proposition 2. Don't Believe (All of) the Hype (Cycle)}

Our second proposition "Don't believe the hype" is a caution to not let our educational technology expectations get carried away. Technology trends usually grow along predictable lines of public interest and development. Gartner (2013) described this process as the Hype Cycle, as shown in Figure 2. In brief, this cycle includes the introduction of a new technology, the new technology exploding in popular knowledge and interest, and the new technology dramatically losing public interest before the last part of the cycle, where the technology slowly increases in use as it is systematically perfected and practical applications using it expand. After this slow increase based on effective use, research and support interest, as well as expectations, plateau at a consistent level of productivity and usage.

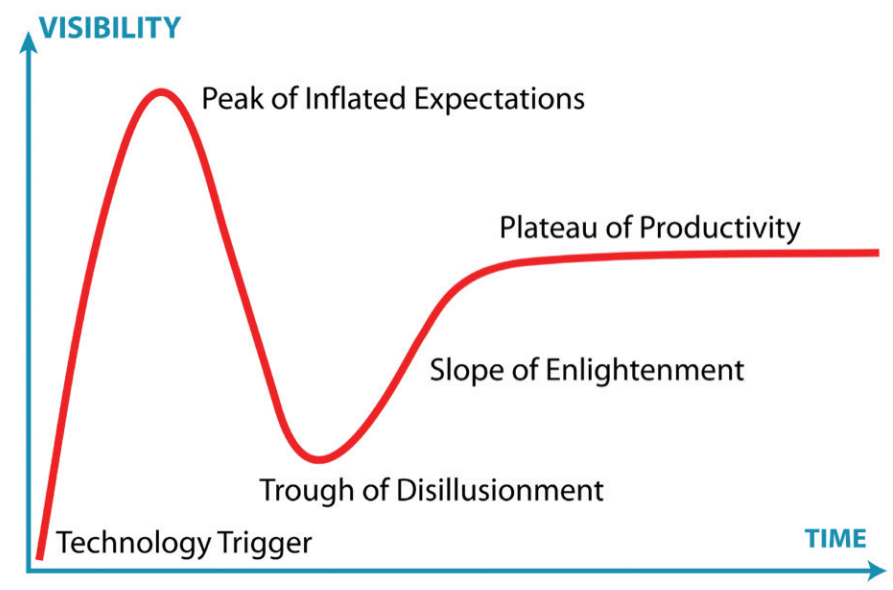

Figure 2. The Gartner Hype Cycle of New Technology. Adapted from Gartner Inc. (2013). 
This cycle occurs repeatedly in technology implementation. Lloyd, Moni and Jobling (2006) demonstrated how the cycle is represented in educational technology in their review of effective computer use for students with intellectual disabilities. For example, when people started reading books on their mobile phones and tablets, many worried that libraries would disappear and that hardcopy books would be lost forever. Instead, paperback novels are again outselling digital copies (Wood, 2017). In this case, the hype of digital books killing off print was overblown. Both digital books and print books remain in wide use. For individuals with disabilities, however, these new digital tools are opening new doors. For example, digital text allows readers with dyslexia to enjoy speech-to-text features that are built into most mobile devices.

\section{Proposition 3. Swish and Flick (and Click)}

Our third proposition is an enthusiastic endorsement to explore and practise new technologies. Just like the students at a certain school of witchcraft and wizardry, the only way to learn is to practise and see what happens. Our first two propositions were mild cautions to remind us that new technologies are not likely to fulfil all the negative or positive outcomes initially imagined. Swish, Flick and Click is the proposition that we just have to try new tools and discover their capabilities and potential first hand. Our belief is that we as educators should be actively engaged with new technologies and encourage our students to do so as well. It is important to realise that technologies can be a panacea for many things, but we still have to do the work. As one of the authors of this paper stated so eloquently, "I am wearing a FitBit on my wrist but my abs have not shown up yet". New immersive learning tools have great potential to support learning, but it is up to us to get in there and work, experiment, adapt, evaluate and try again. In this exponential technology cycle, the only way to effectively bring some of these new technologies to the classroom in a timely way is to build cultures in our schools that embrace taking risks. Unfortunately, multiple studies of teachers' attitudes towards technology show that, while teachers have positive attitudes toward technology, they have significant concerns about their self-efficacy in using these tools and implementing them to support teaching and learning (Teo, Lee, \& Chai, 2008; Teo, 2010).

When we play and explore and allow our students to do the same, strong pedagogies can emerge. Mobile phones can be used for curating notes in class, taking photos of teacher notes written on the board or presented on a slide, recording the teacher's lecture so it can be watched again, reviewing videos on the public transport ride home, and so on. There are many uses for mobile devices in 
education that were not developed by the engineers who created the device. Instead, educators and their students adapted a technology to fit a pedagogical need.

Designing for accessibility from the beginning is an important goal. Consider how the built-in accessibility features of iOS devices helped to propel them to widespread use. Text to Speech and Speech to Text were both once dedicated assistive technologies, but are just now common features of most mobile devices. While a particular option or feature may start as an accessibility option, in time it can become a preferred option for many other users without disabilities, just as many people utilise Text to Speech and AI digital assistants (Siri, Google Now, Cortana) to make appointments.

We can engage with designers, educators, students and other stakeholders to think about creating tools and settings according to user needs. A good example of this in current use are the often little-known aspects of iOS accessibility settings. The text-to-speech and speech-to-text accessibility features are widely used by people without disabilities because of convenience and personal preferences. A similar approach could work in immersive tech. In immersive technology such as AR and VR, which are often very visual heavy, there are still options for designing for accessibility. While you as a designer may find them challenging to implement and plan for, these options for being more inclusive can have unknown benefits. The thought-based controller and haptic feedback prompts that are just prototypes today might develop to become the preferred option for other users without disabilities in the future. Designing for inclusive technology use will always be an ongoing process and dialogue. Assembling a diverse and inclusive set of educational technology superheroes (stakeholders) is a critical part of building an inclusive future with new technologies.

\section{Proposition 4. Super Heroes Assemble}

If we are going to effectively leverage new technologies to design an inclusive future, we must start by being more inclusive educational designers. It is important that we gather a diverse group of developers, teachers, administrators and students to create meaningful learning experiences together. This should embrace marginalised groups, including those with disabilities, in the process. The more opportunities technology experts have to work with and assist educational futurists, students with real needs to run prototypes through, and those in industry to communicate which skills are needed in specific industries, the more able we will be to design curricula that meet all of our students' needs.

We need to look no further than two tech titans, Apple and Google, for examples of how to improve the design process for those with disabilities. In 
addition to including individuals with disabilities in their design and engineering teams, the inclusion of accessibility features in the first iPhone was a gamechanger for individuals with disabilities (Mechling, 2011; McMahon \& Walker, 2014). In 2018, Google introduced a dedicated disability support team to not only take questions from those with disabilities, but also to hear their suggestions for use in future development (Google, 2018). In addition, Google's accessibility blog features stories and examples of how accessibility has been successful in supporting inclusive technology use. Apple and Google were able to do this because they were forward thinking and planned forward rather than trying to retroactively fit features onto technology after the design was complete. They chose to be inclusive voices for those who needed these accessibility features.

The need for interdisciplinary research teams for emerging technologies in education is based on the same principles of bringing diverse groups of stakeholders together. A leading example of this is the creation of the TeachLivE live mixed-reality platform. Mixed reality, which combines elements of VR virtual environments and avatars with real-world interactions, is one example of technology that we know has proven benefits for individuals with disabilities (Walker, in press). Developed at the University of Central Florida, TLE TeachLivE has been shown to improve performance in teacher preparation (Dieker, Hynes, Hughes, \& Smith, 2008). The project involved collaboration between computer scientists, special education technology researchers, $3 \mathrm{D}$ modellers and live actors to create a new platform for simulated practice for teachers, students and other stakeholders to engage in targeted practice of discrete skills. The TLE TeachLivE system is a prime example of the potential of broader interdisciplinary teams to develop new immersive technology interventions.

\section{Proposition 5. Are You Ready for the Remix? (Build on What We Have)}

Our fifth and final proposition "Are you ready for the remix" is a call to connect new technologies to existing education practices. Just like in music, where a remix will take part of the original song that is well established and use it to create a new composition, this is an approach to implementing new technologies.

When new technologies are introduced, we should start by connecting them to existing evidence-based practices and established pedagogical strategies. Research is clear about what works in education, so let us use technology to make those evidence-based practices more efficient, faster and more accessible. We do not have to reinvent the wheel each time a new technology arrives. 
Educators can start with a practice they feel comfortable with and know is important (e.g., formative feedback) and figure out ways to connect technology to the practice (e.g., using voice notes to provide feedback on written work). For individuals with disabilities, immersive technologies have already proven to be important when using evidence-based practices such as video modelling (Cihak et al., 2016) and job coaching (Walker, Vasquez, \& Wienke, 2016). Video modelling on a new technology platform, such as AR, should still be supported as an evidence-based practice that is now being extended to a new platform. Learning communities and educators can create a culture in which remixing old established pedagogical strategies can quickly be adapted to take advantage of a new educational technology tool. Educators can use this remix-friendly culture to bring existing evidence-based practices and pedagogical strategies to successfully implement emerging technologies.

\section{Leveraging Emerging Technology to Design the Inclusive Future}

Emerging technologies are potentially powerful educational tools that can benefit diverse groups of learners, including learners with disabilities. One of the best cases we can make for the use of new technologies in education is that these tools are the technologies that the students will be using when they become adults and join the work force and participate in society as adults. Certainly, these technologies will continue to change and improve, but helping children to discover the current capabilities of these technologies will help them to be more prepared for whatever future forms the technologies may take.

Educational technology researchers are also an important part of this process of responsibly implementing new and potentially disruptive technologies in the classroom. In many cases, peer-reviewed research supporting a new technology will lag far behind the adoption of the technology, but research is still a critical part of the process of new educational technology implementation. If new software can go mainstream in just over a month, like Angry Birds did, obviously conducting a research study, writing it up and publishing it in a peer-reviewed journal is going to take significantly longer. It is also important to remember that, for obvious reasons, research is often undertaken after the peak of the hype cycle. As educational technology researchers, it is often difficult to get into schools to conduct research, because teachers and schools can be very resistant to trying new things in an assessment-based culture. The authors of the present article wrote a manuscript on classroom uses of AR more than five years ago, but it was continually rejected by professional journals because 
there was a lack of evidence. However, schools were unwilling to try the novel technologies even when provided with explicit instructions on how these immersive technologies could benefit instruction. It was not until Pokèmon Go became popular that interest in the article soared and it was published immediately. The hype of AR had finally gone mainstream and the current body of AR in education research is growing (Akçayır \& Akçayır, 2017).

This article presents one of many potential means of addressing the rapidly changing technology landscape and its impact on education. We selected these ideas because they are based on educational research such as the UDL framework, and on our experiences helping educators, families and students adopt new technologies. Future research can either build on or disprove these ideas as effective strategies for using emerging technologies; either way, we need to support educators who are implementing and adopting emerging technologies so that their students are prepared for a future that will have more robotisation, automatisation, artificial intelligence and immersive learning tools.

\section{Conclusion}

Designing the Inclusive Future can be supported by applying these propositions to our lessons and curriculum in order to include new technologies and address new challenges. These emerging technologies can lay the groundwork for a more representative and empowered workforce. What does the future look like? What do our classrooms look like? While robotisation, automatisation, artificial intelligence and immersive learning tools will create new challenges in both the workplace and in education, it is important that we consider how we can prepare our students moving forward. We understand that certainty is safe and comfortable, but it is also important to acknowledge that we will never be fully certain of the potential of technology or the challenges of its use. The implication of innovation is that we will not always know what is going to happen next. The least dangerous assumption is to try to effectively implement new tools in education. The UDL framework and the above propositions are a viable strategy for effective and informed implementation of these technologies in education. While robotisation, automatisation, artificial intelligence and immersive learning technologies will present significant challenges as society adapts, these emerging technologies also present unknown opportunities for new applications supporting inclusion in society and inclusive education environments. In order to address making emerging technologies inclusive, researchers, educators and advocates across many fields need to be engaged in bringing these new technologies into the mainstream. 


\section{References}

Adams, D. (1980). The hitchhiker's guide to the Galaxy. London, UK: Pan Macmillan.

Al-Azawei, A., Serenelli, F., \& Lundqvist, K. (2016). Universal Design for Learning (UDL): A content analysis of peer reviewed journals from 2012 to 2015. Journal of the Scholarship of Teaching and Learning, 16(3), 39-56.

Almond, P., Winter, P., Cameto, R., Russell, M., Sato, E., Clarke-Midura, J., ... Russell, E. M. (2010). Technology-enabled and universally designed assessment: considering access in measuring the achievement of students with disabilities - A Foundation for Research. The Journal of Technology, Learning, and Assessment, 10(5), 4-51.

Aeppel, T. (2015, March 20). It took the telephone 75 years to do what angry birds did in 35 days. But what does that mean? Retrieved from https://blogs.wsj.com/economics/2015/03/13/it-took-thetelephone-75-years-to-do-what-angry-birds-did-in-35-days-but-what-does-that-mean/ Akçayır, M., \& Akçayır, G. (2017). Advantages and challenges associated with augmented reality for education: A systematic review of the literature. Educational Research Review, 20, 1-11. Aquino, S. (2018, July 11). How the iPhone and App Store have redefined accessible software. Retrieved from https://www.macstories.net/stories/how-the-iphone-and-app-store-have-redefined-accessiblesoftware/_

Ayres, K. M., Mechling, L., \& Sansosti, F. J. (2013). The use of mobile technologies to assist with life skills/independence of students with moderate/severe intellectual disability and/or autism spectrum disorders: Considerations for the future of school psychology. Psychology in the Schools, $50(3)$, 259-271.

Bell, V. (2010, February 15). A history of media technology scares, from the printing press to Facebook. Slate Magazine. Retrieved from https://slate.com/technology/2010/o2/a-history-of-mediatechnology-scares-from-the-printing-press-to-facebook.htm Bloom, B. S. (1956). Taxonomy of educational objectives: The classification of educational goals. New York, NY: Longmans, Green.

CAST. (2011). Universal design for learning guidelines version 2.o. Wakefield, MA: CAST.

CAST. (2018). Universal design for learning guidelines version 2.2. [graphic organizer]. Wakefield, MA:

CAST.

Cihak, D. F., Moore, E., Wright, R., McMahon, D. D., Gibbons, M. M., \& Smith, C. (2016). Evaluating augmented reality to complete a chain task for elementary students with autism. Journal of Special Education Technology, 31(2), 99-108.

Dieker, L., Hynes, M., Hughes, C., \& Smith, E. (2008). Implications of mixed reality and simulation technologies on special education and teacher preparation. Focus on Exceptional Children, 4o(6), 1-20.

Dolan, R. P., Hall, T. E., Banerjee, M., Chun, E., \& Strangman, N. (2005). Applying Principles of universal design to test delivery: The effect of computer-based read-aloud on test performance of high school students with learning disabilities. Journal of Technology, Learning, and Assessment, 3(7), 
5-32.

Donnellan, A. M. (1984). The criterion of the least dangerous assumption. Behavioral Disorders, 9(2), 141-150.

Edyburn, D. L. (2010). Would you recognize universal design for learning if you saw it? Ten propositions for new directions for the second decade of UDL. Learning Disability Quarterly, 33(Winter), 33-41.

Edyburn, D. L. (2013). Critical issues in advancing the special education technology evidence base.

Exceptional Children, 8o(I), 7-24.

Every Student Succeeds Act. (2015). Public Law 114-95, 114 U.S.C.

Gartner Inc. (2013). The Hype Cycle. Retrieved from http://www.gartner.com/technology/ research/ methodologies/hype-cycle.jsp

Google. (2018). Introducing the Google disability support team. Google Accessibility Blog. Retrieved from https://www.google.com/accessibility/blog/post/announce-disability-support/

Flores, M., Musgrove, K., Renner, S., Hinton, V., Strozier, S., Franklin, S., \& Hil, D. (2012). A comparison of communication using the Apple iPad and a picture-based system. Augmentative and Alternative Communication, 28, 1-11.

Hall, B. T., Strangman N., \& Meyer, A. (2003). Differentiated instruction and implications for UDL implementation. Access, 9, 2-22.

Higher Education Opportunity Act. (2008). Public Law 110-315 U.S.C.

Ireland, G. V., \& Woollerton, M. (2010). The impact of the iPad and iPhone on education. Journal of

Bunkyo Gakuin University Department of Foreign Languages and Bunkyo Gakuin College, 10, 31-48.

Lloyd, J., Moni, K., \& Jobling, A. (2006). Breaking the hype cycle: Using the computer effectively with learners with intellectual disabilities. Down Syndrome Research and Practice, 9(3), 68-74.

McMahon, D., \& Walker, Z. (2014). Universal design for learning features and tools on iPads and iPhones. Journal of Special Education Technology, 29(2), 39-49

Mechling, L. C. (2011). Review of twenty-first century portable electronic devices for persons with moderate intellectual disabilities and autism spectrum disorders. Education and Training in Autism and Developmental Disabilities, 46(4), 479-498.

Ministry of Education. (2018). Universal Design for Learning (UDL) guide. Retrieved from http:// inclusive.tki.org.nz/assets/inclusive-education/MOE-UDL-guide-summary.pdf National Education Technology Plan. (2016). Future ready learning reimagining the role of technology in education. Washington, D.C.: U.S. Department of Education, Office of Educational Technology. ONCE. (2014). Second International Congress on Disability and University. Retrieved from http://ciud. fundaciononce.es/noticia_det5_en.html

Rao, K., Smith, S. J., Edyburn, D., Grima-Farrell, C., Van Horn, G., \& Yalom-Chamowitz, S. (2018).

UDL Reporting Criteria. Developed by a working group of the Universal Design for Learning Implementation and Research (UDL-IRN) Research Committee. Retrieved from https://udl-irn.org/ udl-reporting-criteria/

Rose, D. H., \& Meyer, A. (2002). Teaching every student in the digital age: Universal design for 
learning. Alexandria, VA: Association for Supervision and Curriculum Development.

Rose, D. H., \& Meyer, A. (2006). A practical reader in universal design for learning. Cambridge, MA: Harvard Education Press.

Scott, L. A. (2018). Barriers with implementing a Universal Design for Learning Framework. Inclusion: 6(4), 274-286.

SIHO. (2015). Universal Design for Learning. Retrieved from: http://siho.pxl.be/

Teo, T. (2010). A path analysis of pre-service teachers' attitudes to computer use: Applying and extending the technology acceptance model in an educational context. Interactive Learning Environments, 18(1), 65-79.

Teo, T., Lee, C. B., \& Chai, C. S. (2008). Understanding pre-service teachers' computer attitudes: applying and extending the technology acceptance model. Journal of Computer Assisted Learning, $24(2), 128-143$.

Thierer, A. (2013). Technopanics, threat inflation, and the danger of an information technology precautionary principle. Tech Minnesota Journal of Law, Science, \& Technology, 14(1), 309.

Turnbull. R., Wehmeyer, M. L., \& Turnbull, A. (2007). Exceptional lives: Special education in today 's schools (5th ed.). Columbus, OH: Merrill/Prentice Hall.

Walker, Z., Sheena, J. E., Wienke, W., \& Tan, D., (2019). A review of interview preparation via virtual and mixed reality for individuals with intellectual and developmental disorder. Vocational Rehabilitation, 51(1), 87-97.

Walker, Z., McMahon, D., \& Rosenblatt, K. (2017). Beyond Pokémon: Augmented reality is a universal design for learning tool. Sage Open, October-December, 1-8.

Walker, Z., Vasquez, E., \& Wienke, W. (2016). The Impact of Simulated Interviews for Individuals with Intellectual Disability. Journal of Educational Technology \& Society, 19(1), 76-88.

Wood, Z. (2017). Book Pricing Figures. Retrieved from https://www.theguardian.com/books/2017/ mar/17/paperback-books-sales-outperform-digital-titles-amazon-ebooks Zero Project. (2014). Innovative Policy 2014 on Accessibility. Retrieved from http://zeroproject.org/ policy/norway/ 


\section{Biographical note}

Don Douglas McMahon, PhD, is an Assistant Professor of Special Education at Washington State University in Pullman, WA. His research interests include: Augmented Reality, Virtual Reality, Wearable devices, Universal Design for Learning, Assistive Technology, and Instructional technology. At WSU Don McMahon coordinates the Assistive Technology Research and Development Lab. He recently was one of the authors of a handbook on using mobile devices in secondary classrooms settings. In addition, he is one of the cofounders of the WSU ROAR postsecondary education program for students with intellectual and developmental disabilities at Washington State University.

ZACHARY WALker, PhD, is an Associate Professor with the University College London Institute of Education (IOE). Zachary serves as the Academic Head of Learning and Teaching for the Department of Psychology and Human Development and leads the Masters in Special Education and Inclusive Education (MASIE) and Masters in International Leadership in Inclusive Education (MAILIE) graduate programs at IOE. He has won numerous international awards and honours. In the last three years, Dr. Walker has worked with educators and policymakers in more than 30 countries on instructional reform, neuroscience, and inclusive pedagogies. 